\title{
The Trials and Significance of Nazi War Criminals and Collaborators in France
}

\author{
By: Gabrielle Marshall
}

Following the trials of Nazi war criminals and collaborators that transpired immediately after World War II, decades passed before the trials of Nazi war criminal Klaus Barbie and French collaborators Rene Bousquet and Maurice Papon. While the reason for the delayed trials differed, the shared relevance of the trials was their allowance for the resurrected testimony of survivors of German occupation and the subsequent Holocaust. Klaus Barbie, otherwise known as the 'Butcher of Lyon,' was convicted of war crimes and sentenced to death in 1952 but with the help of the American government was able to evade capture until 1983. While Barbie's defence lawyer Jacques Verges attempted to deflect his client's crimes by arguing for the immorality of French military actions in Algeria, it was the testimony of Barbie's victims and Holocaust survivors that remained the most prominent and significant aspect of the proceedings. Barbie's trial served as a reminder of the incalculable suffering inflicted by the Nazi regime even by lower level officials and allowed for the humanization of wartime statistics that took on a deeper significance when compiled with the testimony of its victims.

At the same time, the indictments of French collaborators Rene Bousquet and Maurice Papon served as a reminder to the French population of the role of the Vichy government in the execution of Nazi policy as they collaborated in the deportation and systematic killing of the Jewish population. In 1949, Bousquet, the General Secretary of the Police, was tried and convicted of national unworthiness and sentenced to five years in prison but had his sentence commuted because of his last-minute aid of a group of Resistance fighters destined for execution. It was not until 1991, following an illustrious 
postwar career as a banker and businessman, that Bousquet was indicted for crimes against humanity. However, he was assassinated in 1993 before his trial began. A victim of vigilante justice, Bousquet was never properly tried for his crimes, allowing for the testimony of his victims to be lost and the narrative surrounding his name to be focused on his own violent death. In contrast, Papon, the Secretary General of the Gironde Prefecture from 1942 to 1944, faced his trial in 1997 for his role in the deportation of 1,560 Jews from Bordeaux to concentration camps. While Papon, like Bousquet, enjoyed decades of success in the postwar era, a 1981 exposé began the chain of indictments that culminated in his 1998 conviction for crimes against humanity. The Papon trial was significant because it garnered widespread attention from the media and brought the extent of French collaboration during World War II to the forefront of the national zeitgeist decades after the events transpired. While the trials of Barbie, Bousquet, and Papon occurred long after the initial wave of postwar convictions, their significance was compounded by the emergence of occupation and Holocaust survivors who created a legal and historical record of the horrors of the Nazi regime and the function of French collaboration in its execution.

Throughout World War II Klaus Barbie became notorious for the extreme acts of violence he committed against members of the French Resistance and the Jewish residents of Lyon while they were held under Nazi occupation. After joining the Nazi movement in 1934 Barbie was accepted into the SS, and by 1942 he had become the head of the Gestapo in Lyons, the centre of the Resistance in the south of France. It was reported that under Barbie's command in the final two years of occupation he had about 
4,000 people executed in Lyons and another estimated 8,000 deported to death camps. ${ }^{1}$ In this time, Barbie earned the title of 'Butcher of Lyon' from his routine use of torture to extract information from members of the Resistance, as well as those of the Jewish faith. At the end of the war the French government placed Barbie on its list of war criminals to be tried but by 1947 Barbie was working with the American Counter Intelligence Corps (CIC) gathering intel on communist organizations. ${ }^{2}$ In spite of his work with the CIC Barbie was tried in absentia at the Permanent Military Tribunal of Lyon in 1952 for the murder of civilians and torture of military personnel. ${ }^{3}$ While Barbie was convicted and sentenced to death he evaded capture with the help of the American government and immigrated to Bolivia where he lived under an assumed name. Barbie remained in hiding until 1983 when the Bolivian government complied with a French arrest warrant and extradited Barbie back to France to await trial. Due to various legal inquiries the trial did not commence until $1987 .{ }^{4}$ The delay in the trial was largely due to the statute of limitations on war crimes and the inability to retry crimes of which he had already been convicted, ultimately negating many of the charges laid against him. Barbie was, however, charged with crimes against humanity for certain incidents including the raid of the Union Generale des Israelites de France (UGIF), the arrest and deportation of 44 children and their caretakers from Izieu, and a deportation of 650 people in one of the last convoys to leave Lyon bound for a concentration camp. ${ }^{5}$

\footnotetext{
${ }^{1}$ Guyora Binder, "Representing Nazism: Advocacy and Identity at the trial of Klaus Barbie," Yale Law Journal 98, no. 7 (1989): 1325.

${ }^{2}$ Ibid, 1325-1326.

${ }^{3}$ Christian Delage, "The Klaus Barbie Trial: Traces and Temporalities," Comparative Literature Studies 48, no. 3 (2011): 320.

${ }^{4}$ Binder, 1326.

${ }^{5}$ Delage, 320-321.
} 
Significant to Barbie's trial proceedings was the defence used by his lawyer Jacques Verges, who had previously defended several known terrorists and enemies of France. In a defence strategy that Verges referred to as 'rupture,' he continually attempted to mitigate the crimes of Barbie by bringing up allegations of French torture and murder during the Algerian War. ${ }^{6}$ In addition to Verges' accusations of French conduct in the Algerian War, he also detailed the storied record of French collaboration and discussed the hypocrisy of some French Resistance heroes. ${ }^{7}$ Verges wanted to use the performative nature of the Barbie trial to "put a mirror to France's own raddled face," to prove that the French government had no basis of morality on which to judge Barbie's actions. ${ }^{8}$ While effective in making headlines, the prosecution quickly highlighted distinctions between actions of the French in Algeria and the crimes of the Nazi regime. As Guyora Binder notes, the prosecution indicated that it was the ideologically motivated and systematic nature of the crimes committed by the Nazis, Barbie included, that made them distinct as crimes against humanity. ${ }^{9}$ Thus, while the prosecution had to connect all of Barbie's crimes to the Nazi ideology, it allowed for the prosecution to move forward, as the French had defined their actions in Algeria as a crime of war, distinct from Barbie's crimes against humanity. Verges went on to protest that the trial had become a persecution of an ideology and not the judgement of a single man. While Verges was able to create a media frenzy around French crimes in Algeria, it was the testimony of Barbie's victims that consistently brought the significance of the trial back into focus. Barbie was convicted for crimes against humanity and sentenced to life imprisonment

\footnotetext{
6 "Jacques Verges; Notorious French Lawyer who 'defended the indefensible' including the Nazi War Criminal Klaus Barbie," The Times (17 August 2013).

${ }^{7}$ Ibid.

${ }^{8}$ Ibid.

${ }^{9}$ Binder, 1338.
} 
due to France's recent abolishment of the death penalty and served his sentence until his death in 1991.

On 4 July 1987, a month after Barbie's trial commenced, journalist Michael McCarthy published an article in The Times discussing the significance of putting an old man on trial decades after his crimes were committed. ${ }^{10}$ McCarthy's article is significant as he discusses not only the need for justice for those who died at Barbie's order, but the necessity of humanization of Holocaust statistics as the survivors entered the witness box to painfully recount their stories of torture and death. ${ }^{11}$ The courtroom presence of survivors and the families of those killed during Barbie's trial served as a reminder to the public that, decades after the conflict had ended, the wounds of occupation were still present. Additionally, as mentioned in the testimony of Léon Reifman, a survivor of the UGIF raid, the lack of regret expressed by Barbie left many in search of a larger meaning to his conviction. As Reifman noted, his hope was that "not so much out of vengeance, but as a lesson for history ... through this one man the whole ideology that dishonours mankind might itself be condemned." 12 The nature of the Barbie trial indicates that a crucial aspect of the post-war memory in France was the distinction between the French and the Nazi party and removal of any implication of collaboration or similarity. This was evident in the deflection of Verges' allegation of French crimes against humanity in Algeria, as the French court went on to define their own crimes as distinct for their lack of Nazi ideology. Thus, Barbie's trial served as a symbolic education for a new generation about the incalculable suffering inflicted by the Nazi party, in addition to establishing a complete separation of Nazi activity from French nationalism.

\footnotetext{
10 "Barbie-Now I Know Why They Bothered," The Times (1987).

${ }^{11}$ Ibid.

${ }^{12}$ Delage, 329.
} 
Another significant postwar trial in the latter half of the twentieth century was that of Rene Bousquet, an ambitious politician who rose to prominence under the Laval administration as the General Secretary of the Police in 1942. Bousquet argued that collaboration was the only way to preserve some semblance of French autonomy. Bousquet indicated that the Vichy government had to permit French police to carry out German orders to avoid increased destruction and harm to the French population, which may have come at the hands of German forces. ${ }^{13}$ In his own perverse attempts to keep the peace Bousquet went beyond the necessities of collaboration and duty, as he and Prime Minister Laval proposed the inclusion of Jews under the age of 16 into deportations. ${ }^{14}$ But in an effort to reduce public outcry Bousquet proposed the deportation of foreign Jews from both the occupied and unoccupied zones of France in exchange for leaving French Jews alone, at least for the time being. ${ }^{15}$ During the Rafle du Vel' d'Hiv on 16 and 17 June 1942, roughly 13,000 Jews were rounded up in Paris while a reported 47,000 more were deported from the rest of the country and sent to concentration camps before being filtered into death camps. ${ }^{16}$ Bousquet was tried in 1949 for his wartime activities and sentenced to five years for collaboration, but due to his last minute protection of Resistance officials in 1943 before he lost his position as chief of police, his sentence was suspended and Bousquet served no jail time. Throughout his trial no questions regarding Bousquet's role in mass Jewish deportations were explored. This was most likely due to the efforts of officials to mitigate the role of French collaboration in the war and in the

\footnotetext{
${ }^{13}$ Daniel Singer, "Death of a Collaborator," Nation 257, no. 3 (1993): 201.

${ }^{14}$ Ian Buruma, "The Vichy Syndrome," Tikkun 10, no. 1 (1995): 44.

15 Ibid.

${ }^{16}$ Eric Epstein, "Fit to be Tried: Maurice Papon and the Vichy Syndrome. Defeat and Collaboration," Journal of Genocide Research 1, no. 1 (1999): 119.
} 
mass murder of the Jewish population. This is evident in the fact that, until 1983, French history textbooks described Jewish deportations as a wholly German effort. ${ }^{17}$

Indicative of the postwar amnesia regarding French collaboration was Bousquet's ability to resume his life as a notable figure, enjoying success in banking as well as selling luxury goods before retiring to a posh Paris apartment. By 1953, the French government had passed two amnesty laws that ended legal action against officials involved in the Vichy regime, but significantly these laws allowed for the persecution of those who carried out criminal Nazi policies. ${ }^{18}$ While such laws signified the end of the initial flow of persecutions of Vichy officials, it did leave room for the trials of collaborators thought to have carried out the will of Nazi ideology. Thus, in 1991 Bousquet was set to go on trial for charges of crimes against humanity regarding the Rafle du Vel' d'Hiv as well as his cancellation of regulations that would have protected certain classes of Jewish children from deportation. But Bousquet never made it to trial as Christian Didier assassinated him on 8 June 1993. Thus, he was never formally tried and brought to justice for his role in the deportation of thousands of Jews.

According to Serge Klarsfeld, the attorney who filed the suit against Bousquet in 1989 for crimes against humanity and was instrumental in the capture of Klaus Barbie, Bousquet's trial was to have two major theses. "One thesis is that the Vichy regime was criminal, because of its persecution of the Jews," he argued. "The other is that it was not, because under the circumstances it could not have acted otherwise." ${ }^{\prime 19}$ But following the precedent of Barbie's sentence to life imprisonment, of which he only served four years before his death, it left many French feeling that their courts were too humane and that

\footnotetext{
${ }^{17}$ Ibid.

${ }^{18}$ Delage, 321.

${ }^{19}$ Buruma, 44.
} 
vigilante justice was the only means of retribution. One such man was Christian Didier, born in 1944 in Nazi-occupied France. In 1987 Didier pretended to be a doctor and snuck into the prison that held Barbie in an attempt to assassinate him for his murder of French Resistance leader Jean Moulin. ${ }^{20}$ While Didier failed and spent a year in prison, he succeeded in his assassination of Bousquet. After disguising himself as a carrier of official documents for the upcoming trial, Didier gained access to Bousquet's building and shot him when he opened the door to receive the package. ${ }^{21}$ While there were undoubtedly many French who did not mourn the death of Bousquet, the loss of his trial was significant since the trials provided more than mere vengeance against an individual, but aided in resurrecting the past as part of the collective memory of the French people. Many leaders in the French Jewish community as well as Klarsfeld, who had worked for over a decade to bring Bousquet to trial, had hoped that such a high profile trial would force French citizens to acknowledge the extent of French collaboration during the war. ${ }^{22}$ While Bousquet did not go unpunished for his crimes, the extent of French collaboration and the thousands deported were no longer the focus, as his name became part of the collective memory as a victim of vigilante justice. This misappropriation of facts allowed for postwar amnesia about French collaboration to continue and thus further inhibited the ability of French citizens to accept their chequered past.

Another significant trial was that of collaborator Maurice Papon, the former Secretary General of the Gironde Prefecture, charged with crimes against humanity for the deportation of 1,560 Jews from Bordeaux, 223 of which were children. Most of those deported were sent to Auschwitz where a majority were murdered. In his time as

\footnotetext{
${ }^{20}$ Ibid.

${ }^{21}$ Ibid.

22 "I Was Good and he Was Evil," Newsweek 121, no. 25 (21 June 1993): 44.
} 
Secretary, General Papon was in charge of traffic, rationing gas, requisitions, as well as Jewish questions, in which Papon supervised the identification of Jews and the redistribution of their possessions to non-Jews. ${ }^{23}$ In spite of Papon's collaboration during the war, his political career did not suffer, and he was able to maintain positions of power in the Fourth and Fifth Republics, serving as Charles De Gaulle's Police Prefect of Paris from 1958 until 1966 and the budget minister from 1978 until 1981 when damning accusations were brought forth by the families of the Jewish deportees. ${ }^{24}$ Significant to Papon's time as Prefect of the Paris Police was his connection to the savage suppression of demonstrators against the Algerian War in which an estimated 100 people were beaten to death or drowned in the River Seine by the Paris Police force. ${ }^{25}$ While it is unlikely Papon encouraged the violence that occurred, he refused to acknowledge that anything unjust occurred in the suppression of Algerian protestors, a fact that was used in his subsequent trial.

In 1983, following a highly publicized 1981 exposé in Le Canard Enchaîné in which he was accused of the deportation of Jews from Bordeaux, Papon was formally indicted for crimes against humanity. Investigations followed and new indictments were issued in 1991, and following the conviction of fellow Vichy collaborator Paul Touvier in 1994 there were more indictments for Papon and an increased call to see him tried. ${ }^{26} \mathrm{~A}$ major issue that stalled Papon's trial was the establishment of his guilt in the death of those whom he had deported, as it was widely held that it was not through ideological

\footnotetext{
${ }^{23}$ Keith Coloquhoun and Ann Wroe, "Maurice Papon," Economist Book of Obituaries (2008): 286.

${ }^{24}$ Nancy Wood, "Memory in Trial in Contemporary France: The Case of Maurice Papon," History and Memory 11, no. 1 (1999): 50.

${ }^{25}$ Richard J. Golsan, "Memory's Bombes à Retardement: Maurice Papon, Crimes Against Humanity, and 17 October 1961," Journal of European Studies 28, no. 1-2 (1998): 153.

${ }^{26}$ Wood, 50.
} 
agreement with the Nazi party or an entrenched anti-Semitism that Papon carried out Nazi policy. Papon's rationale for collaboration was closer to that of Bousquet as he argued for the need to participate in deportation and subjugation of the Jewish population in Bordeaux in order to maintain French autonomy in government and mitigate the presence of Germans in France. ${ }^{27}$

Throughout the investigation into Papon's crimes between 1995 and 1996, the prosecution worked to establish that, because Papon had taken the position of Secretary General of the Gironde Prefecture with the knowledge that Germans aimed to deport Jews to the east, he would have therefore been aware of the fate awaiting them. His acceptance of the position subsequently indicated a general approval of Nazi policy. ${ }^{28}$ During the Nuremberg trials, crimes against humanity were defined as criminal acts against a specific group of people, while the French trials placed culpability in the establishment of ideologically motivated action, as was made evident in the trial of Barbie in the defense of French actions in Algeria. Significant to Papon was a 1997 ruling of the Supreme Court of Appeal, which stated that it was no longer necessary to prove ideological complicity in order to be found guilty of crimes against humanity. ${ }^{29}$ Papon's trial began in October of 1997 and went on for six months, the longest in French history. Due to the French government's ruling that the court no longer had to establish ideological adherence, Papon was convicted of crimes against humanity and sentenced to ten years in prison. During his trial, the lawyer for the prosecution Arno Klarsfeld, son of Serge Klarsfeld, asked Papon "to voluntarily participate in something one knows to be a crime - doesn't that amount to being complicit in it, even without having desired the

\footnotetext{
${ }^{27}$ Ibid, 51 .

${ }^{28}$ Ibid.

${ }^{29}$ Ibid, 52.
} 
consequences?" to which Papon replied, "in law or in morality?" ${ }^{30}$ While Papon's potential knowledge of the Final Solution could not be legally confirmed nor denied, it was his refusal to disobey orders and remove himself from his political post within the collaborating regime that allowed the jury to find Papon guilty. Papon's sentencing was significant because, in spite of simply following orders from his superiors and playing a relatively low-ranking position in the Vichy government, he was unable to deflect individual blame for his role in the deportation and eventual death of 1,560 Jews.

In 1999, following a rejected appeal of his case, Papon fled to Switzerland stating he would rather live in exile than face a French jail. Papon was quickly extradited back to France where he served his jail time until advanced age and illness meant a release only three years into his sentence. ${ }^{31}$ Significantly, during Papon's trial the Catholic Church, the office of the Magistrate, and the French police force apologized for their actions under the Vichy regime, indicating a massive shift in public discourse on French collaboration during World War II. Additionally, mass media coverage on television as well as in print—including several articles on Vichy and Papon in every issue of French newspaper Le Monde for the six-month trial— indicated that French society was not ignoring their past. ${ }^{32}$ As Nancy Wood argues, Papon's trial offered an opportunity for analysis of the specific function of the Vichy administration in the execution of the Nazi's Final Solution. ${ }^{33}$ The trial of Papon, much like that of Barbie and others complicit in the realization of Nazi policy, served as not only a stage for justice but for officially recording the trauma of their victims. Additionally, Papon's trial allowed for the

\footnotetext{
${ }^{30}$ Wood, 60.

${ }^{31}$ Craig R. Whitney, "Maurice Papon, Convicted Vichy Official, 96, Dies," The New York Times (18 February 2007).

${ }^{32}$ Richard Vinen, "Papon in Perspective," History Today 48, no. 7 (1998): 6.

${ }^{33}$ Wood, 57.
} 
reinstatement of memories of occupation into the French collective consciousness. It thus educated a new generation and provided an established public record of French collaboration.

While many questioned the necessity of indicting and trying old men for crimes they committed decades prior, it is evident in the cases of Klaus Barbie, Rene Bousquet, and Maurice Papon that the crimes they committed during the German occupation of France left wounds that remained painful and relevant to survivors and the families of those who died. The trial of Barbie allowed for public acknowledgment of the magnitude of human suffering caused by even low-level officials within the Nazi regime, as well as the resurrection of testimonies of Holocaust survivors into the collective memory of World War II. While Bousquet was assassinated before trial, the indictment of his crimes and the publicity surrounding his death, albeit not entirely focused on his crimes nor his victims, brought a rise in public awareness that the deportation of Jews was not an entirely German affair. In addition to Bousquet, the trial and conviction of Papon incited discussion of the role of the French government in the execution of the Final Solution. In spite of the indictments of Barbie, Bousquet, and Papon occurring decades after they committed their respective crimes against humanity, their trials established a legal and historical record of those who died under German occupation and the role of the collaboration of the French government in the execution of the Final Solution. 


\section{Bibliography}

"Barbie-Now I Know Why They Bothered.” The Times (4 July 1987).

Binder, Guyora. "Representing Nazism: Advocacy and Identity at the trial of Klaus Barbie.” Yale Law Journal 98, no. 7 (1989): 1321-1383.

Buruma, Ian. “The Vichy Syndrome.” Tikkun 10, no. 1 (1995): 44-50.

Coloquhoun, Keith and Ann Wroe. "Maurice Papon." Economist Book of Obituaries (2008): 286-287.

Delage, Christian. "The Klaus Barbie Trial: Traces and Temporalities." Comparative Literature Studies 48, no. 3 (2011): 320-332.

Epstein, Eric. "Fit to be Tried: Maurice Papon and the Vichy Syndrome. Defeat and Collaboration.” Journal of Genocide Research 1, no. 1 (1999): 115-121.

Golsan, Richard J. "Memory's Bombes à Retardement: Maurice Papon, Crimes Against Humanity, and 17 October 1961. "Journal of European Studies 28, no. 1-2 (1998): 153-172.

“I Was Good and He Was Evil.” Newsweek 121, no. 25 (21 June 1993), 44.

“Jacques Verges; Notorious French Lawyer Who 'Defended the Indefensible' Including the Nazi War Criminal Klaus Barbie.” The Times (17 August 2013).

Singer, Daniel. "Death of a Collaborator." Nation 257, no. 3 (1993): 101-103.

Vinen, Richard. "Papon in Perspective." History Today 48, no. 7 (1998): 6-8.

Whitney, Craig R. "Maurice Papon, Convicted Vichy Official, 96, Dies.” The New York Times (18 February 2007).

Wood, Nancy. "Memory in Trial in Contemporary France: The Case of Maurice Papon." History and Memory 11, no. 1 (1999): 41-76. 